\title{
4-H boosts youth scientific literacy with ANR water education curriculum
}

by Martin H. Smith, Katherine E. Heck and Steven M. Worker

Scientific literacy among $K-12$ youth in the United States needs to be improved, and UC Agriculture and Natural Resources has identified this as a key area for research and extension. In 2010, ANR developed a water education curriculum for implementation by 4- $\mathrm{H}$, which has a record of successful, nonformal science education programming that complements classroom-based instruction. The development of the new curriculum, There's No New Water!, is described, and preliminary results from a pilot test with high school youth are provided. Preliminary outcomes showed gains in both science knowledge and life skills.

$\mathrm{T}$ wenty-first-century society is highly dependent on science and requires a scientifically literate population (NAS 2007). Individuals who lack fundamental science knowledge and skills risk being unqualified for many careers and unable to participate fully in society (Miller 2006). In particular, citizens need to understand scientific concepts and theories in order to address important issues such as public health, water quality, agriculture, transportation, communication and energy conservation (NAS 2007). The National Academy of Sciences maintains that a scientifically literate population is critical for a robust national economy driven by "well-trained people and the steady stream of scientific and technical innovations they produce" (NAS 2007).

Research has revealed, however, that scientific literacy in the United States is low. Miller (2006) found that only $28 \%$ of U.S. adults have a level of scientific understanding necessary to function as citizens in modern society, and scientific literacy among young people is also undesirably low. Nationally, assessments have shown stagnant or declining science scores among school-age youth. The

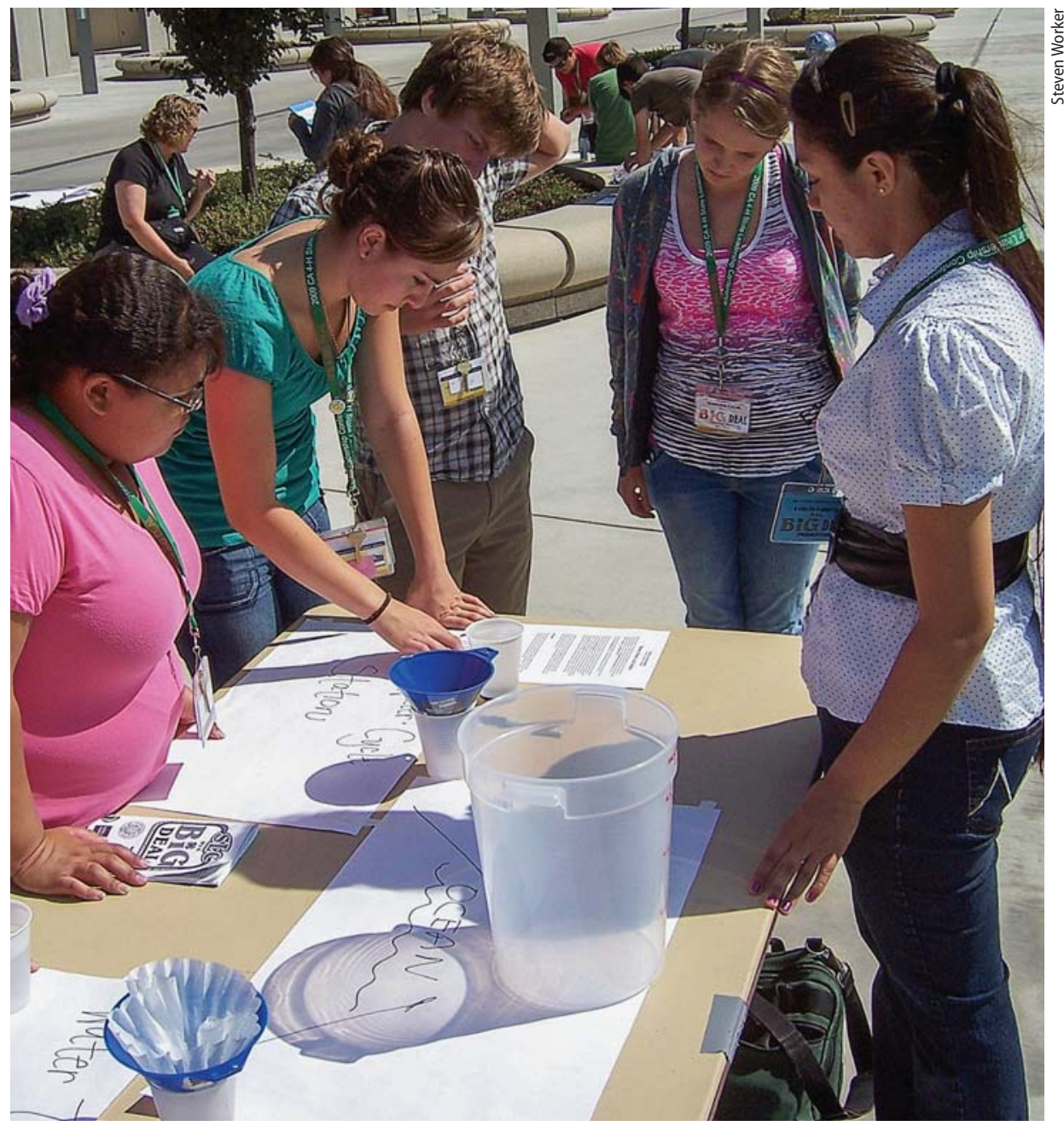

The 4-H curriculum There's No New Water! was developed in response to ANR's Strategic Vision 2025 , and it is guided by National 4-H Science literacy goals and strategies. During a workshop at UC Merced, 4-H members simulate the pathways raindrops may traverse through a watershed.

2005 and 2009 National Assessment of Educational Progress (NAEP) results for 4th, 8th and 12th graders showed poor science achievement at all three grade levels (Grigg et al. 2006; NCES 2011). These trends are not distributed equally across the population; science achievement tends to be higher among male than female students, white and Asian American than black and Latino youth, and those from high-income than from low-income households (Grigg et al. 2006; NCES 2011). State-level data show that California is not an exception to the poor national achievement in science.

Low scientific literacy has compromised the nation's ability to train new scientists, as demonstrated by the decline in the number of college science graduates. It is also evident in the drop in production of new scientific knowledge by U.S. scientists compared with that of scientists in many other developed nations over the past 20 years (NAS 2007). For these reasons, identifying effective strategies to address low scientific literacy among youth is imperative.

\section{Learning in nonformal programs}

Achieving higher scientific literacy among the school-age population will

Online: http://californiaagriculture.ucanr.edu/ landingpage.cfm?article=ca.v066n04p158\&fulltext=yes DOl: $10.3733 /$ ca.v066n04p158 
require a variety of complementary strategies, including nonformal science programs that occur outside of school. On average, U.S. citizens spend less than 5\% of their lives in classrooms, and a growing body of evidence demonstrates that most science is learned outside of school (Falk and Dierking 2010). Science learning out of school may actually be more effective than learning in classroom settings (Sullenger 2006). Nonformal learning environments generate excitement around science that encourages learners to explore and interact with the subjects and to think of themselves as able to use science in everyday life (Bell et al. 2009).

Adult staff members or volunteer educators usually lead nonformal education programs with youth (Carlson and Maxa 1997). These opportunities can occur in a variety of venues, including after-school and school enrichment programs, clubs, camps or museums. Nonformal education programs emphasize learner-centered strategies that engage participants to develop their knowledge and reflect on how science takes place in the real world (Carlson and Maxa 1997). Learnercentered strategies engage youth in an active manner through hands-on activities that involve problem solving, critical thinking and active reflection. This is in contrast to more traditional classroombased approaches such as lectures and demonstrations. Although not considered to be alternatives to school, nonformal education programs can expand school curriculum offerings and complement classroom teaching (Kahler and Valentine 2011).

\section{ANR's Strategic Vision 2025}

UC Agriculture and Natural Resources (ANR) connects the research base of the university to local communities throughout the state. Its Strategic Vision 2025 charts a course of action for the role ANR will play in "improving California's future by providing leadership and innovation through research, education and service" over the next 15 to 20 years (ANR 2009). In descriptions of targeted strategic initiatives, the document outlines plans for science-based solutions to issues and challenges facing California's environmental, agricultural and human resources.
Scientific literacy is a key issue targeted for applied research, education and extension efforts. In integrated, multidisciplinary approaches outlined in the Healthy Families and Communities (HFC) Initiative (Campbell et al. 2010), the university has committed to improving scientific literacy among Californians. The Initiative's plan describes the need to develop and implement science programs that use active-learning strategies, involve schools and community-based education programs and increase civic engagement among target audiences, particularly youth. Delivering educational programs at the community level is a cornerstone of ANR's efforts to increase scientific literacy.

Water supply and quality for agricultural, urban and environmental systems are additional focal concerns outlined in ANR's Strategic Vision 2025 (ANR 2009). Specifically, the Initiative to Improve Water Quality, Quantity, and Security suggests that the following issues need attention: water availability due to competition among different sectors of the population, short- and long-term climate changes that will affect water supplies, the degradation of water quality, and legal and regulatory decisions that will affect water availability, use and quality. Strategies outlined by the Strategic Vision 2025 for UC ANR personnel to address these problems include research, education and partnerships with agricultural and environmental groups and regulatory agencies.

\section{4-H Youth Development}

The National 4-H Youth Development Program has provided nonformal educational opportunities to youth ages 5 through 19 since its establishment by Congress in 1914, and it is one of the largest communitybased youth organizations in the world. Using strategies that engage youth in hands-on, learner-centered projects and programs, 4-H staff and adult volunteers serve as nonformal educators and deliver 4-H projects and activities that address the interests of young people and help meet the needs of their communities (Enfield 2001). California $4-\mathrm{H}$ is the youth education program of UC ANR.

The 4-H program offers a wide variety of educational opportunities that reflect its diverse membership (Enfield 2001). Nationally, more than $50 \%$ of all $4-\mathrm{H}$ members participate in science projects and activities, ranging from geology and minerals to soil conservation, from forestry to wildlife and fisheries, from computer science to animal and veterinary science (USDA 2003). In California, over $130,0004-\mathrm{H}$ youth were enrolled in science, engineering or technology programming during the 2009-2010 school year (UC ANR 2012).

Outcome data from evaluations shows that 4-H plays a vital role in helping U.S. youth contribute to their communities (Lerner et al. 2012). 4-H youth are almost twice as likely as other youth to make community contributions; additionally, they have higher measures of civic duty, civic voice and participation in volunteer activities (Lerner et al. 2009). Likewise, youth who participate in 4-H are more likely than other young people to have a positive attitude toward science (Lerner et al. 2009).

Youth who have more exposure to 4-H science, engineering and technology programs are more likely to agree that science is their favorite subject, and they are more likely to want to pursue a job in science (Mielke et al. 2010). In addition, 
youth engaged in 4-H science programs take higher-level science coursework in high school compared with young people outside of 4-H (Heck et al. 2012). Furthermore, youth in the California 4-H program are more likely than other young people to report that programs they participate in after school and in the summer increase their interest in taking more science courses as they get older, as well as their interest in pursuing science as a career (Heck 2009).

\section{California 4-H SET Initiative}

In 2007, National 4-H Headquarters developed the 4-H Science Mission Mandate (Schmiesing 2008). Grounded in research that indicates the importance of community-based programs in improving youth scientific literacy (Bell et al. 2009), this mandate established programmatic priorities to help guide state 4-H programs' efforts to develop and implement new, research-based curricula, as well as develop staff and volunteers, partnerships, evaluation and funding sources (Schmiesing 2008).

In 2008, California 4-H launched its 4-H Science, Engineering and Technology (SET) Initiative as a direct response to the National 4-H Science Mission Mandate. The SET Initiative has youth scientific development and implementation of effective SET-based curriculum materials that align with UC ANR priorities and support county-based 4-H SET programming.

\section{There's No New Water!}

In response to the Strategic Vision 2025, ANR academic staff developed the youth science curriculum There's

\section{Educational programs based on high-quality curriculum materials are most relevant for young people when they reflect societal needs and concerns.}

literacy as its overarching goal and aims to improve existing 4-H SET programming and develop new programming that aligns with the initiatives outlined in ANR's Strategic Vision 2025 (ANR 2009). One major focus of the California 4-H SET Initiative plan of action is the

\section{There's No New Water! Table of Contents}

1. The Natural Water Cycle

Activity 1: Where in the World is Water?

Activity 2: $\mathrm{H}_{2} \mathrm{O}$ by the Numbers

Activity 3: Can You Make it Rain?

Activity 4: Where Water Flows: An Introduction to Watersheds

2. Human Interventions in the Water Cycle Activity: From the Storm Clouds to the Ocean: Chance Encounters of Wandering Water

3. Water as an Available Resource: The Urban/Rural Interface

Activity 1: Watersheds and the Urban/Rural Interface Activity 2: Population Growth and the Changing Face of the Urban/Rural Interface: 2010-2025

4. Mapping Natural Watersheds Activity 1: Water Flows Downhill: An Introduction to Topographical Maps Activity 2: Mapping Locations of Point and Nonpoint Source Pollutants in Watersheds: Predicting Impacts; Identifying Solutions

5. Service Learning Projects in your Watershed

Step 1: Identifying Needs in Your Community

Step 2: Preparing the Project

Step 3: Experiencing Service

Step 4: Evaluating the Project

Step 5: Sharing the Project

6. Teens Teaching Younger Youth

Activity 1: The Earth's Water: Streams, Lakes, Oceans, \& More!

Activity 2: How Much Water Do We Use?

Activity 3: What Goes Down Your Drain?

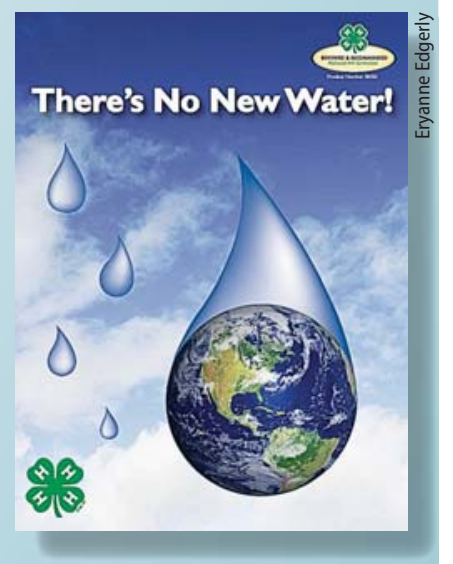

No New Water! (Smith et al. 2010). This peer-reviewed curriculum, published by National 4-H Council, focuses on increasing scientific literacy by engaging middle and high school youth in hands-on, inquiry-based science activities that include opportunities for real-world applications of knowledge and skills through service learning. The sequenced activities build learners' knowledge and skills by emphasizing interrelated concepts, support state and national science standards, and are applicable for use in schools and community-based education programs.

There's No New Water! was developed using the backward design method (Wiggins and McTighe 1998), which involves identifying learning objectives and indicators before designing activities. Once the objectives and indicators were outlined, the curriculum design team, consisting of ANR academic staff and university undergraduates, formed subgroups focused on specific content areas. Each subgroup then engaged in an iterative process that involved reviewing relevant literature, drafting and pilot testing activities, and collecting formative data (qualitative information on content and processes used) for revisions. The curriculum includes elements outlined by Siemer (2001) for effective water stewardship education: sequential learning experiences that occur over time, opportunities to develop relevant ecological knowledge, and skill building such as decision making, communication and evaluation.

Educational programs based on highquality curriculum materials are most relevant for young people when they reflect societal needs and concerns (Ediger 2002). The major themes of There's No New 
Water! are priority issues in California and nationally: water distribution and water availability, conservation and quality. Topics include the natural water cycle, watersheds, human interventions in the water cycle, the urban/rural interface and topographic mapping of watersheds in different geographic locations (see box).

Curriculum activities support the National Science Education Standards (NRC 1996), and they include explorations of science processes, scientific inquiry, natural resources and environmental quality, and natural and human-induced hazards. Furthermore, the curriculum addresses specific science content standards for California public schools for grades 9 to 12 - California geology and water $(9 \mathrm{c}$ and $9 \mathrm{~d}$ ) and skills in investigation and experimentation (1a, $1 \mathrm{~d}, 1 \mathrm{~h}, 1 \mathrm{l}$ and $1 \mathrm{~m})$ (CDE 2003).

A unique feature of There's No New Water! is the opportunity for youth to engage in their community through service learning. In module five, guidelines help youth identify water-related issues in their community and develop a project to address them. This application of learning is particularly germane to improving scientific literacy and also workforce preparedness; engaging youth in inquiry relevant to their community has been shown to increase their interest in science (Eick et al. 2008). Module six includes age-appropriate activities on water resources designed for implementation by teens with elementary school youth. Research-based strategies that help teens to have a successful experience teaching younger youth are provided (Lee and Murdock 2001). Teens have been shown to be extremely effective teaching science to younger youth; they relate well to younger audiences, are optimistic in their roles as cross-age teachers and engage in science content and processes with children in an active manner (Ponzio et al. 2000).

\section{Testing the curriculum}

A school enrichment program was used to pilot test There's No New Water! and collect preliminary outcome data. School enrichment programs are often used to implement 4-H youth science programs (Kahler and Valentine 2011), which have been shown to provide experiential education opportunities in school

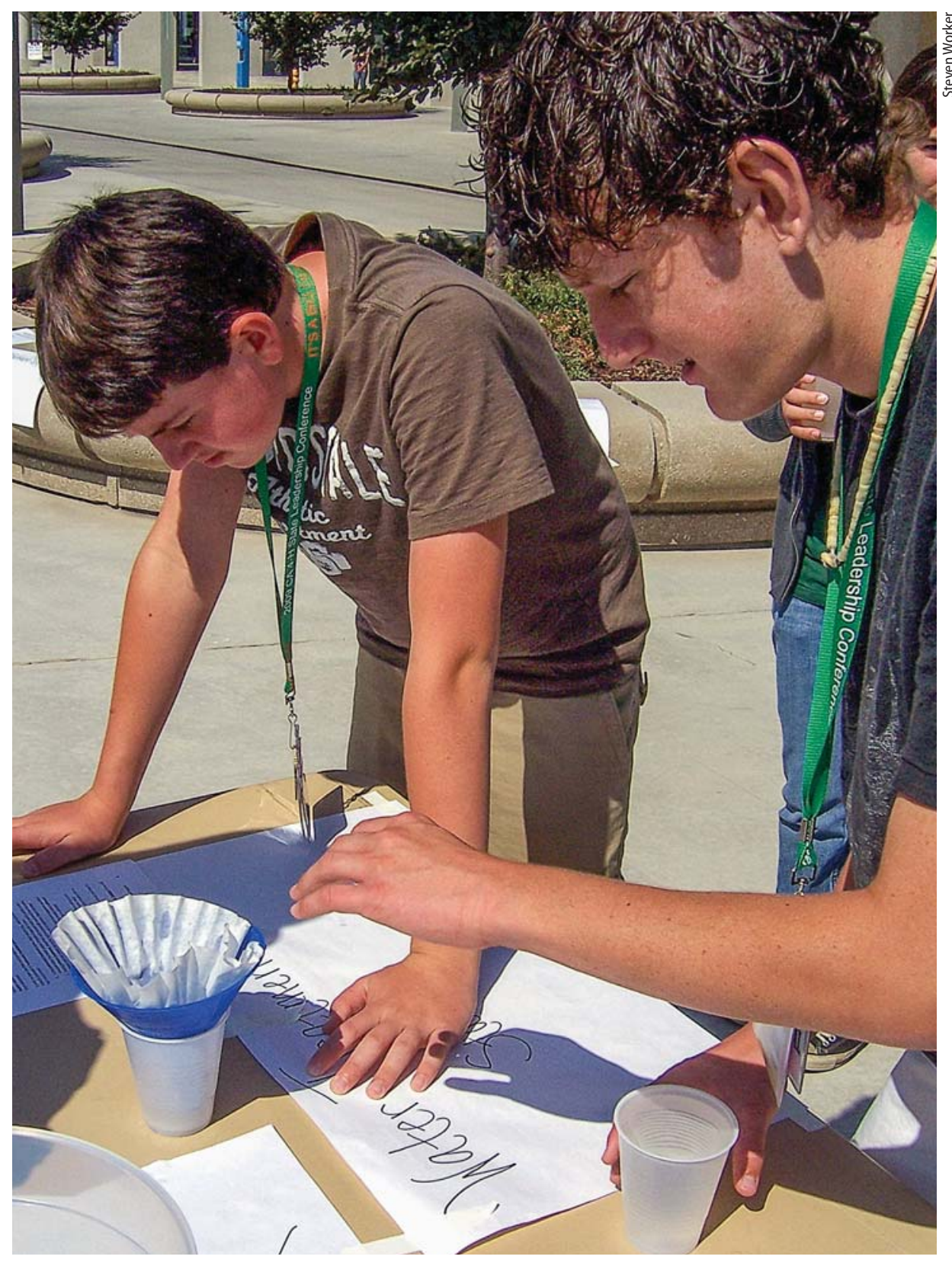

Participants at the "water treatment" station learn that wastewater must be treated for harmful pathogens, toxins and organic matter that can have damaging effects on human health and the watershed. There's No New Water! includes a module to help youth identify local water concerns and develop a program to address them, activities shown to increase interest in science.

settings, increase participating youths' knowledge and skills and help reach diverse audiences (Diem 2001).

Modules one through four of the curriculum were implemented once per week for 1 hour over an 8-week period with students in two ninth-grade earth science classes in a north-central California urban high school. The curriculum was offered in lieu of the students' regular class instruction. Modules five and six were not offered due to time constraints.

A retrospective pretest survey was used to examine changes in content knowledge (Pratt et al. 2000). Participants self-reported how much knowledge they believed they had gained in content areas related to water resources. A retrospective pretest design can provide a more accurate assessment of change due to a program intervention than other types of survey methodologies (Pratt et al. 2000). Specifically, this type of survey design reduces the problem of response-shift bias, which is the overestimation of knowledge and skills on a pretest that can occur when using a pretest versus posttest comparison (Pratt et al. 2000). Furthermore, 
a retrospective pretest design helps reduce the time needed to administer the survey and mitigates the challenge of obtaining complete data sets (Raidl et al. 2004).

A second survey was used to investigate youths' perceived gains in various life skills from participating in the activities (Hendricks 1996). Using a posttest design, this survey replicated questions from previously published evaluation research on life skills outcomes from participation in Cooperative Extension programming (Bailey and Deen 2002).

Six UC Davis undergraduate students were recruited as volunteer educators to implement There's No New Water! with participating youth in the pilot program. They were trained over a 10 -week period in effective scienceteaching strategies and all of the curriculum activities. The high school where the pilot evaluation occurred is located in a mid-sized city and serves approximately 1,900 students from 9 th to 12 th grade. Approximately $22 \%$ of the school's students receive free or reduced-price meals, and about $10 \%$ are classified as English learners or reclassified as English proficient.

A total of 59 youth, aged 14 to 17, participated in the pilot evaluation; most were 14 or 15 , and $58 \%$ were male.
Approximately $29 \%$ of the participants reported that they were Latino, 10\% were black, $14 \%$ were Asian or Pacific Islander, 37\% were white, and $10 \%$ were other or did not report their race/ ethnicity.

\section{Preliminary results}

Participants were asked eight retrospective pretest questions on content knowledge (e.g., on global water distribution, point and nonpoint source pollutants, watersheds and urban/rural interface) to ascertain their perceived level of knowledge gain. On a scale of 1 (poor) to 4 (excellent), responses to all eight questions revealed a statistically significant $(P<0.01)$ increase in self-perceived knowledge gain using a paired $t$-test comparison of the means (table 1).

The 20 questions on the second survey related to life skills, including wise use of resources, social skills, communication and responsible citizenship, as specified in the Targeting Life Skills Model (Hendricks 1996). Participants rated their levels of knowledge gain using a scale from 1 (not at all) to 4 (a lot). The means

\begin{tabular}{|c|c|c|c|}
\hline \multicolumn{4}{|c|}{$\begin{array}{l}\text { TABLE 1. Mean change in level of knowledge around } \\
\text { There's No New Water! content topics }\end{array}$} \\
\hline Topic & $\begin{array}{l}\text { Level of } \\
\text { knowledge } \\
\text { before }\end{array}$ & $\begin{array}{l}\text { Level of } \\
\text { knowledge } \\
\text { after }\end{array}$ & $\begin{array}{l}P \text { value for } \\
\text { difference }\end{array}$ \\
\hline $\begin{array}{l}\text { Global water } \\
\text { distribution }\end{array}$ & $1.85^{*}$ & 2.54 & $<0.01$ \\
\hline Water conservation & 1.83 & 2.53 & $<0.01$ \\
\hline $\begin{array}{l}\text { Nonpoint source } \\
\text { pollutants }\end{array}$ & 1.65 & 2.33 & $<0.01$ \\
\hline Watershed & 1.43 & 1.97 & $<0.01$ \\
\hline Topographic maps & 2.00 & 2.75 & $<0.01$ \\
\hline Urban/rural interface & 1.66 & 2.32 & $<0.01$ \\
\hline Point source pollutants & 1.92 & 2.49 & $<0.01$ \\
\hline $\begin{array}{l}\text { Water quality in my } \\
\text { community }\end{array}$ & 1.78 & 2.34 & $<0.01$ \\
\hline
\end{tabular}

TABLE 2. Mean gain in selected life skills for There's No New Water! curriculum

\begin{tabular}{ll}
\hline \hline & Mean \\
Life skills & value* $^{*}$ \\
\hline Water and environment & 2.66 \\
I improved my ability to think about and understand concepts related to water. & 3.10 \\
I learned the importance of protecting the natural environment. & 2.97 \\
I learned ways I can help improve the environment. & \\
Citizenship, leadership and responsibility & 2.80 \\
I learned how my actions affect my community and the world. & 2.58 \\
I improved my ability to accept responsibility that comes with being a good citizen. & 2.27 \\
I improved my ability to involve others in sharing leadership responsibilities. & \\
Social skills, cooperation and communication & 2.63 \\
I improved my ability to help out as best I can when working with a group. & 2.64 \\
I improved my ability to cooperate with others toward a goal. & 2.56 \\
I improved my ability to relate to others socially. & 2.55 \\
I improved my ability to listen carefully to what others say. & 2.27 \\
\hline I improved my ability to clearly state my thoughts and ideas to others. &
\end{tabular}


for their responses ranged from 2.3 (a little) to 3.1 (some), with the greatest perceived gains reported around citizenship and helping the environment (table 2).

\section{Success and future of program}

The preliminary learner outcomes from the pilot test support previous researchers' assertions on the importance of nonformal science education programming (Bell et al. 2009) and how such programs can expand school curriculum offerings and complement classroom teaching (Kahler and Valentine 2011). The outcomes are also congruent with the goals of the California 4-H SET Initiative, the National 4-H Science Mission Mandate and ANR's Strategic Vision 2025 to strengthen curriculum materials and programming for youth in science (ANR 2009; Kahler and Valentine 2011). They also address the ANR Strategic Vision 2025 directives on improving citizens' understanding of water issues, why and how to care for the environment and ways to conserve natural resources.

The preliminary results presented build a case for an in-depth evaluation of There's No New Water! in multiple nonformal contexts, including 4-H clubs, after-school programs and camps, using multiple measures to improve the validity and reliability of the findings. The curriculum is currently being implemented through county-based 4-H programs in California, as well as in 4-H programs in numerous other states. It is available for purchase through the National
4-H Program's Curriculum Resource Library (www.4-h.org/resource-library/ curriculum).

M.H. Smith is Associate Specialist, Veterinary Medicine Extension, UC Davis; K.E. Heck is Research Analyst, Department of Family and Community Medicine, Center on Social Disparities in Health, UC San Francisco; and S.M. Worker is 4-H Science, Engineering, Technology (SET) Initiative Coordinator, State 4-H Office, UC Davis.

The authors acknowledge the UC Davis undergraduates who contributed to the development, graphic design and pilot testing of the There's No New Water! curriculum. Additionally, the authors thank Maggi Kelly for her contributions to the curriculum content, and Sharon Junge and Stephanie Gallagher for their roles in conceptualizing the project. The National 4-H Council funded the curriculum development and pilot test.

\section{References}

[ANR] UC Division of Agriculture and Natural Resources. 2009. UC ANR Strategic Vision 2025. Oakland, CA: http:// ucanr.org/files/906.pdf.

Bailey S, Deen M. 2002. Development of a web-based evaluation system: A tool for measuring life skills in youth and family programs. Fam Relat 51(2):138-47.

Bell P, Lewenstein B, Shouse A, Feder M (eds.). 2009. Learning Science in Informal Environments: People, Places, and Pursuits. Washington, DC: Nat Acad Pr. 336 p

Campbell D, Chen Z, Crawford P, et al. 2010. Healthy Families \& Communities Strategic Plan. UC ANR. http:// ucce.ucdavis.edu/files/workgroups/7233/10-4-10_HFC_ Strategic_Plan.pdf.

Carlson S, Maxa S. 1997. Science Guidelines for Nonfor mal Education. US Department of Agriculture, Cooperative Extension Service, Children, Youth, and Family Network. www1.cyfernet.org/prog/schl/science/4h590. html.

[CDE] California Department of Education. 2003. Science Content Standards for California Public Schools: Kindergarten through Grade Twelve. Sacramento, CA. www.cde. ca.gov/be/st/ss/documents/sciencestnd.pdf.

Diem K. 2001. National 4-H school enrichment survey. J Extension 39(5). www.joe.org/joe/2001october/rb6.php. Ediger M. 2002. Societal Trends and the Curriculum. No. ED473944. ERIC Clearinghouse on Assessment and Evaluation. College Park, MD.

Eick C, Deutsch B, Fuller J, Fletcher S. 2008. Making science relevant: Water-monitoring programs help student study science while protecting local waterways. Sci Teach 75(4):26-9.

Enfield RP. 2001. Connections between 4-H and John Dewey's Philosophy of Education. Focus (winter). 4-H Center for Youth Development, Department of Human and Community Development, UC Davis. www.ca4h.org/ files/1234.pdf.

Falk J, Dierking L. 2010. The 95\% solution: School is not where most Americans learn most of their science. Am Sci 98(6):486-93.

Grigg WS, Lauko MA, Brockway DM. 2006. The Nation's Report Card: Science 2005. US Department of Education National Center for Education Statistics. http://nces. ed.gov/nationsreportcard/pubs/main2005/2006466. asp\#pdflist.
Heck KE. 2009. 4-H Impacts Young People's Interest in Science, Engineering, and Technology. 4-H Center for Youth Development, UC Davis. www.ca4h.org/files/1319.pdf. Heck KE, Carlos RM, Barnett CC, Smith MH. 2012. 4-H participation and science interest in youth. J Extension 50(2). www.joe.org/joe/2012april/a5.php.

Hendricks PA. 1996. Developing youth curriculum using the targeting life skills model: Incorporating developmentally appropriate learning opportunities to assess impact of life skill development. Tech Rep No 4H-137A. lowa State University Extension. Ames, IA.

Kahler J, Valentine N. 2011. Stemming the gap. Educ Digest 76(6):54-5.

Lee F, Murdock S. 2001. Teenagers as teachers program: Ten essential elements. J Extension 39(1). www.joe.org/ joe/2001february/rb1.php.

Lerner RM, Lerner JV, et al. 2012. The Positive Development of Youth: Report of the Findings from the First Eight Years of the 4-H Study of Positive Youth Development. National 4-H Council. Chevy Chase, MD. www.4-h.org/ WorkArea/DownloadAsset.aspx?id=61090

Lerner RM, Lerner JV, Phelps E, et al. 2009. The Positive Development of Youth: Report of the Findings from the First Five Years of the 4-H Study of Positive Youth Development. National 4-H Council. www.4-h.org/uploadedFiles/About_4-H/Research/4-H-study-of-positiveyouth-development.pdf.

Mielke M, LaFleur J, Sanzone J. 2010. 4-H Science, Engineering, and Technology (SET) Initiative: Youth Engagement, Attitudes, and Knowledge Study. Policy Studies Associates. www.4-h.org/uploadedFiles/About_Folder/ Research/Science/2009\%204-H\%20Science\%20YEAK\%20 Report.pdf.

Miller J. 2006. Civic Scientific Literacy in Europe and the United States. World Association for Public Opinion Research. Montreal, Can. www.arcsfoundation.org/Pittsburgh/JMiller.pdf.

[NAS] National Academy of Sciences. 2007. Rising above the Gathering Storm: Energizing and Employing America for a Brighter Economic Future. Washington, DC: Nat Acad Pr. $592 \mathrm{p}$.

[NCES] National Center for Education Statistics. 2011 The Nation's Report Card: Science 2009. NCES 2011 451. Institute of Education Sciences, US Department of Education. http://nces.ed.gov/nationsreportcard/pdf/ main2009/2011451.pdf.
[NRC] National Research Council. 1996. National Science Education Standards: Observe, Interact, Change, Learn. Washington, DC: Nat Acad Pr. 262 p. www.archive.org/ details/nationalsciencee00natirich.

Ponzio RC, Junge SK, Smith MH, et al. 2000. 4-H teens as science teachers of children. In: Braverman MT, Carlos RM, Stanley SM (eds.). Youth Development Programming: Reviews and Case Studies from the University of California. UC ANR Pub 3401. Oakland, CA. p 75-91.

Pratt CC, McGuigan WM, Katzev AR. 2000. Measuring program outcomes: Using retrospective pretest methodology. Am J Eval 21:341-9.

Raidl M, Johnson S, Gardiner K, et al. 2004. Use retrospective surveys to obtain complete data sets and measure impacts in Extension programs. J Extension 42(2). www. joe.org/joe/2004april/rb2.php.

Schmiesing RJ. 2008. 4-H SET Mission Mandate. www. national4-hheadquarters.gov/library/SET_fall08_update. pdf.

Siemer WF. 2001. Best practices for curriculum, teaching and evaluation components of water stewardship education. In: Felder AJ (ed.). Defining Best Practices in Boating Fishing, and Stewardship Education. Recreational Boating \& Fishing Foundation. Alexandria, VA. p 18-36.

Smith M, Worker S, Kelly M, et al. 2010. There's No New Water! National 4-H Council. Chevy Chase, MD. 155 p.

Sullenger K. 2006. Beyond school walls: Informal education and the culture of science. Educ Canada 46(3):15-8. [UC ANR] UC Agriculture and Natural Resources. 2012 California 4-H Enrollment Data from the ES237 Participation Count Report for 2009-2010. UC Youth, Families, and Communities Statewide Program. Davis, CA.

[USDA] US Department of Agriculture. 2003. Annual 4-H Youth Development Enrollment Report, 2003 Fiscal Year. Cooperative State Research, Education, and Extension Service. Washington, DC.

Wiggins G, McTighe J. 1998. Understanding by Design. Association for Supervision and Curriculum Development. Alexandra, VA. 207 p. 